\title{
MEKANISME PENYELESAIAN SENGKETA KONSTRUKSI MENURUT UNDANG-UNDANG NOMOR 2 TAHUN 2017 TENTANG JASA KONSTRUKSI
}

\author{
Mas Agus Priyambodo \\ Sekolah Tinggi Ilmu Hukum IBLAM \\ Kramat Raya No.25, Senen, Jakarta Pusat \\ Email :masagus9383@gmail.com
}

Submisson : 6 Agustus 2021

Accepted : : 10 september 2021

Publish : 30 September 2021

\begin{abstract}
In essence, construction projects arise because of the convergence of two interests. On the one hand, there is a demand (demand) from the Service User, on the other hand the Service Provider offers its service (offer). Therefore, law number 2 of 2017 concerning Construction Services in Article 1 Paragraph (5) and (6) defines Service Users as owners or employers who use Construction Services, while Service Providers are providers of Construction Services. Construction is a very complex industry, this is because in construction projects there are multiple disciplines and dealing with many people who have their own interests. This condition also opens up opportunities for greater disputes. Disputes in construction work contracts or construction disputes are events that sometimes arise and cannot be avoided in the execution of the contract. The causes of this also vary from both internal and external factors. The problem in this paper is how to resolve construction disputes according to law number 2 of 2017 concerning construction services. The research used is normative legal research, which relies on secondary data as the main data source. The results showed that after the issuance of Law no. 2/2017 concerning Construction Services, construction disputes must first be resolved through deliberation for consensus. If the disputing parties do not find an agreement, then the settlement is taken through the stages of dispute resolution as regulated in the construction work contract. Then if the dispute resolution is not stated in the construction work contract, then the parties with written approval will regulate the dispute resolution procedure chosen.
\end{abstract}

Keywords : Construction contracts, Dispute resolution.

\begin{abstract}
Abstrak
Hakikatnya proyek konstruksi timbul karena bertemunya dua kepentingan. Di satu sisi muncul permintaan (demand) dari Pengguna Jasa, di sisi lain Penyedia Jasa menawarkan layanannya (offer). Karena itu, dalam undang-undang nomor 2tahun 2017 tentang Jasa Konstruksi dalam Pasal 1 Ayat (5) dan (6) mendefinisikan Pengguna Jasa sebagai pemilik atau pemberi pekerjaan yang menggunakan layanan Jasa Konstruksi, sedangkan Penyedia Jasa adalah pemberi layanan Jasa Konstruksi. Konstruksi adalah salah satu industri yang sangat kompleks, hal ini karena dalam proyek konstruksi terdapat multi disiplin ilmu dan berurusan dengan orang banyak yang memiliki kepentingan masing- masing. Kondisi ini pula yang membuka peluang
\end{abstract}


sengketa menjadi lebih besar. Sengketa dalam kontrak kerja konstruksi atau construction dispute adalah kejadian yang terkadang timbul dan tidak dapat dihindari dalam pelaksanaan kontrak. Penyebab terjadinya pun bermacam-macam baik dari faktor internal maupun eksternal. Permasalahan dalam tulisan ini yaitu Bagaimanakah penyelesaian sengketa konstruksi menurut undang-undang nomor 2 tahun 2017 tentang jasa konstruksi, Penelitian yang digunakan adalah penelitian hukum normatif yaitu mengandalkan data sekunder sebagai sumber data utama. Hasil penelitian menunjukkan bahwa Setelah terbitnya UU No. 2/2017 tentang Jasa Konstruksi, sengketa konstruksi terlebih dahulu diselesaikan melalui musyawarah untuk mufakat. Apabila para pihak yang bersengketa tidak menemukan kesepakatan, maka penyelesaian ditempuh melalui tahapan penyelesaian sengketa yang diatur dalam kontrak kerja konstruksi. Kemudian apabila penyelesaian sengketa tidak tercantum dalam kontrak kerja konstruksi, maka para pihak dengan persetujuan tertulis mengatur mengenai tata cara penyelesaian sengketa yang dipilih.

Kata Kunci : Kontrak konstruksi, Penyelesaian sengketa.

\section{A. Pendahuluan}

Indonesia merupakan sebuah negara berkembang yang sedang secara serius dan terus melakukan pembangunan, pada saat ini telah dilaksanakan pembangunan di segala bidang baik pembangunan di bidang fisik maupun di bidang non fisik secara merata. Oleh karena itu hasil-hasil pembangunan harus dapat dinikmati seluruh rakyat Indonesia sebagai upaya untuk meningkatkan kesejahteraan baik lahir dan batin secara adil dan merata demi terwujudnya kesejahteraan dan menciptakan kemakmuran bagi seluruh rakyat Indonesia.

Berhasil tidaknya pembangunan sangat tergantung pada partisipasi seluruh rakyat, yang berarti bahwa pembangunan harus dilaksanakan secara merata oleh segenap lapisan masyarakat. ${ }^{1}$ Salah satu bidang pembangunan itu adalah pembangunan di bidang ekonomi yang diwujudkan dalam bentuk pembangunan fisik berupa gedung perkantoran, perumahan, pelabuhan, industri, jalan, jembatan dan lain-lainnya.

Dalam hal ini semuanya memerlukan pengaturan yang tegas baik dari segi yuridis maupun segi teknisnya yang perlu dikembangkan serta ditingkatkan pelaksanaannya. ${ }^{2}$

Pada dhakikatnya tidak seorangpun yang menghendaki terjadinya sengketa dan perselisihan dengan orang lain. Tetapi dalam hubungan bisnis atau suatu perjanjian, masing-masing pihak harus mengantisipasi kemungkinan munculnya

\footnotetext{
${ }^{1}$ F.X. Djumialdji (1), Hukum Bangunan, Dasar-Dasar Hukum dalam Proyek dan Sumber Daya Manusia, (Jakarta : PT. Rineka Cipta, 1996), hlm.1

${ }^{2}$ F.X. Djumialdji (2), Perjanjian Pemborongan, (Jakarta : PT. Rineka Cipta, 1991), hlm.1
} 
sengketa yang dapat terjadi setiap saat dikemudian hari. Sengketa dapat timbul karena dilatarbelakngi oleh beberapa hal diantaranya perbedaan penafsiran baik mengenai bagaimana cara melaksanakan klausulk-lausul perjanjian maupun tentang apa isi dari ketentuan- ketentuan didalam perjanjian, atau pun disebabkan hal-hal lainnya. ${ }^{3}$

Proses penyelesaian sengketa melalui pengadilan atau yang disebut juga dengan litigasi menghasilkan keputusan yang bersifat menang dan kalah yang belum mampu merangkul kepentingan bersama, dan hal tersebut cenderung menimbulkan masalah baru, penyelesaian yang lambat, membutuhkan biaya yang mahal, serta dapat menimbukan permusuhan diantara para pihak yang bersengketa.

Oleh karena beberapa kekurangan penyelesaian sengketa melalui pengadilan itulah maka sebagian orang lebih memilih penyelesaian sengketa diluar pengadilan. ${ }^{4}$ Berdasarkan hal diatas, maka hal yang hendak penulis rumuskan yaitu bagaimana mekanisme penyelesaian sengketa konstruksi menurut undang- undang nomor 2 tahun 2017 tentang jasa konstruski, Tujuan penulisan ini yaitu untuk mengetahui dan menganalisa bagaimana mekanisme penyelesaian sengketa konstruksi menurut undangundang-undang nomor 2 tahun 2017 tentang jasa konstruksi.

Adapun untuk menganalisis keseluruhan data yang terkumpul, menggunakan metode analisis Deskriptif dan Interpretatif.

1. Metode deskriptif analitis, dimaksudkan untuk memberikan data yang seteliti mungkin tentang keadaan atau gejala-gejala lainnya. Maksudnya adalah untuk mempertegas hipotesa-hipotesa, agar dapat membantu teori-teori lama, atau di dalam kerangka menyusun teori- teori baru. ${ }^{5}$ Analisis deskriptif ini dilakukan untuk menggambarkan konsep dan praktik dalam pelaksanaan Putusan Majelis Hakim tentang tindak pidana perjudian online jenis togel Singapura.

2. Metode analisis interpretasi, digunakan untuk mengadakan penelusuran terhadap azas-azas yang terdapat di dalam hukum positif dan menghubungkannya dengan fungsi hakim dalam menerapkan hukum, khususnya di dalam melakukan penafsiran terhadap peraturan perundangundangan. ${ }^{6}$ Metode ini akan penulis gunakan untuk mendalami Putusan majelis hakim nomor 660/Pid.Sus/2019/PN Jkt.Utr

\footnotetext{
${ }^{3}$ Gatot Soemartono, arbitrase dan mediasi di Indonesia, PT Gramedia Pustaka Utama, Jakarta2006, hlm 1.

${ }^{4}$ Nazharkhan Yasin, Mengenal Klaim Konstruksi dan penyelesaian sengketa konstruksi, PTGramedia Pustaka Utama, Jakarta 2008, hlm 84.

5 Soerjono Soekanto, Pengantar Penelitian Hukum, Jakarta: Universitas Indonesia press, 1986,hlm. 10

${ }^{6}$ Ibid, hlm. 252
} 
tentang tindak tindak pidana perjudian jenis togel Singapura secara online baik secara eksplisit maupun implisit untuk menafsiri, memposisikan dan membandingkan agar dapat mengungkap dasar pertimbangan hukum yang terkandung di dalamnya.

\section{Tinjauan Teoritis dan Yuridis}

Pengertian Sengketa Sengketa dapat terjadi pada siapa saja dan dimana saja. Sengketa dapat terjadi antara individu dengan individu, antara individu dengan kelompok, antara kelompok dengan kelompok, antara perusahaan dengan perusahaan, antara perusahaan dengan negara, antara negara satu dengan negara lainnya. Dengan kata lain, sengketa dapat bersifat publik maupun keperdataan dan dapat terjadi baik dalam lingkup lokal, nasional maupun internasional. Sengketa adalah suatu perkara yang terjadi antara para pihak yang bersengketa di dalamnya mengandung sengketa yang harus diselesaikan oleh kedua belah pihak. ${ }^{7}$

Sengketa dalam kamus Bahasa Indonesia berarti pertentangan atau konflik. Konflik berarti adanya oposisi atau pertentangan antara orangorang, kelompokkelompok, atau organisasi-organisasi terhadap satu objek permasalahan. Pertentangan atau konflik yang terjadi antara individu-individu atau kelompok- kelompok yang mempunyai hubungan atau kepentingan yang sama atas suatu objek kepemilikan, yang menimbulkan akibat hukum antara satu dengan yang lain. ${ }^{8}$ Konflik atau sengketa merupakan situasi dan kondisi di mana orangorang saling mengalami perselisihan yang bersifat faktual maupun perselisihan-perselisihan yang ada pada persepsi mereka saja. ${ }^{9}$

\section{Penyelesaian Sengketa Melalui Pengadilan (Litigasi)}

Menurut Suyud Margono berpendapat bahwa:" "Litigasi adalah gugatan atas suatu konflik yang diritualisasikan untuk menggantikan konflik sesungguhnya, dimana para pihak memberikan kepada seorang pengambilan keputusan dua pilihan yang bertentangan." Litigasi merupakan proses penyelesaian sengketa di pengadilan, di mana semua pihak yang bersengketa saling berhadapan satu sama lain untuk mempertahankan hak-haknya di muka pengadilan. Hasil akhir dari suatu penyelesaian sengketa melalui litigasi adalah putusan yang menyatakan win- lose solution. ${ }^{11}$ Prosedur dalam jalur litigasi ini sifatnya lebih formal (very formalistic) dan sangat teknis (very technical). Seperti yang dikatakan J. David Reitzel "there is a long wait for litigants to get trial", jangankan untuk mendapat

\footnotetext{
${ }^{7}$ Sarwono,2012, HUKUM ACARA PERDATA Teori dan Praktik, Jakarta: Sinar Grafika, hlm.7

${ }^{8}$ Winardi, Managemen Konflik (Konflik Perubahan dan Pengembangan), Mandar Maju, Bandung,2007, hlm. 1 .

${ }^{9}$ Takdir Rahmadi, Mediasi Penyelesaian Sengketa Melalui Pendekatan Mufakat, Rajawali Pers,Jakarta, 2011, hlm

${ }^{10}$ Suyud Margono, ADR dan Arbitrase: Proses Pelembagaan dan Aspek Hukum, Ghalia Indonesia,Bogor, 2004, hal. 23

${ }^{11}$ Nurnaningsih Amriani, Mediasi Alternatif Penyelesaian Sengketa di Pengadilan, GrafindoPersada, Jakarta, 2012, hlm. 16
} 
putusan yang berkekuatan hukum tetap, untuk menyelesaikan pada satu instansi peradilan saja, harus antri menunggu. ${ }^{12}$ Litigation (bahasa Inggris) artinya pengadilan. Jadi nonlitigasi adalah di luar pengadilan. Sebagai bahan perbandingan, litigation (pengadilan), sebagian besar tugasnya adalah menyelesaikan sengketa dengan menjatuhkan putusan (constitutive) misalnya menjatuhkan putusan atas sengketa waris, perbuatan melawan hukum dan sebagian kecil tugasnya adalah penangkalan sengketa dengan menjatuhkan penetapan pengadilan (deklaratoir) misalnya penetapan wali, penetapan anak angkat dan lain-lain. ${ }^{13}$

\section{Penyelesian sengketa nonlitigasi}

Nonlitigasi sebagai kebalikan dari litigasi (argumentum analogium) adalah untuk menyelesaikan sengketa di luar pengadilan melalui perdamaian dan penangkalan sengketa dengan perancanganperancangan kontrak yang baik. Penyelesaian sengketa secara nonlitigasi meliputi bidang yang sangat luas bahkan mencakup seluruh aspek kehidupan yang dapat diselesaikan secara hukum. ${ }^{14}$ Penyelesaian sengketa secara nonlitigasi adalah penyelesaian sengketa di luar pengadilan yang didasarkan kepada hukum, dan penyelesaian tersebut dapat digolongkan kepada penyelesaian yang berkualitas tinggi, karena sengketa yang diselesaikan secara demikian akan dapat selesai tuntas tanpa meninggalkan sisa kebencian dan dendam. Dengan demikian, penyelesaian sengketa secara nonlitigasi adalah penyelesaian masalah hukum secara hukum dan nurani, sehingga hukum dapat dimenangkan dan nurani orang juga tunduk untuk mentaati kesepakatan/ perdamaian secara sukarela tanpa ada yang merasa kalah. Penyelesaian sengketa melalui proses di luar pengadilan menghasilkan kesepakatan yang bersifat "win-win solution", dijamin kerahasiaan sengketa para pihak, dihindari kelambatan yang diakibatkan karena hal prosedural dan administratif, menyelesaikan masalah secara komprehensif dalam kebersamaan dan tetap menjaga hubungan baik.

Penyelesaian sengketa non litigasi juga dikenal dengan istilah ADR (Alternative Dispute Resolution). ${ }^{15}$ Penyelesaian sengketa di luar pengadilan atau yang lebih dikenal dengan Alternative Dispute Resolution (ADR) dapat ditempuh dengan berbagai cara. ADR tersebut dapat berupa: ${ }^{16}$

\section{a. Arbitrase;}

\footnotetext{
${ }^{12}$ Yahya Harahap, Hukum Acara Perdata Tentang Gugatan, Persidangan, Penyitaan, Pembuktian,dan Putusan Pengadilan, Sinar Grafika, Jakarta, 2009, hlm. 233.

${ }^{13}$ I Wayan Wiryawan \& I Ketut Artadi, Penyelesaian Sengketa Di Luar Pengadilan. Denpasar -Bali :

Udayana University Press, 2010.

${ }^{14}$ ibid

152 Frans Hendra Winata, Hukum Penyelesaian Sengketa, Sinar Grafika, Jakarta, 2012, hlm. 25

${ }^{16}$ Yahya Harahap, Beberapa Tinjauan Mengenai Sistem Peradilan dan Penyelesaian Sengketa,Citra Aditya Bakti, Bandung, 1997, hlm. 186
} 
b. Mediasi;

c. Konsiliasi;

d. Minitrial;

e. Summary jury trial;

f. Seetlement conference;

g. Serta bentuk lainnya.

\section{B. Hasil Penelitian dan Pembahasan}

Sengketa konstruksi lazim terjadi terutama mengingat praktik dalam jasa konstruksi yang sarat dengan resiko dan berbagai kepentingan. Pelaksanaan proyek konstruksi diawali dengan kontrak konstruksi yang telah menjabarkan kondisi-kondisi apabila terjadi sengketa konstruksi dan prosedur penanganannya. Sengketa konstruksi cenderung timbul apabila salah satu pihak menganggap bahwa pihak lainnya telah melakukan pelanggaran terhadap kewajiban dan tanggungjawabnya. ${ }^{17}$

Penyelesaian sengketa Konstruksi menurut Pasal 88 Ayat (1) Undang-undang Nomor 2 Tahun 2017, diselesaikan dengan prinsip dasar musyawarah untuk mencapai kemufakatan. Apabila tidak tercapai suatu kemufakatan, para pihak yang bersengketa menempuh tahapan upaya penyelesaian sengketa yang tercantum dalam Kontrak Kerja Konstruksi. Apabila ternyata didalam kontrak jasa konstruksi tidak tercantum upaya penyelesaian sengketa, maka para pihak yang bersengketa dapat membuat suatu persetujuan tertulis mengenai tata cara sengketayang akan dipilih.

Perselisihan pelayanan konstruksi terbagi dalam tiga bagian $:^{18}$

a. Perselisihan "precontractual" adalah sebelum dibuatnya perjanjiantelah terjadi sengketa, atau masih dalam proses pelelangan.

b. Perselisihan "contractual" yaitu Terjadinya suatu perselisihan padasaat berjalannya pelaksanaan tersebut.

c. Sengketa "pascacontractual" yaitu Terjadinya suatu sengketa saatbangunan tersebut digunakan atau sudah digunakan selama 10 tahun.

Jika perselisihan yang terjadi waktu melaksanakan pekerjaan itu diartikan proses kontrak sudah disepakati oleh kedua belah pihak, di tandatangani, serta sudah dilaksanakan di lapangan. Biasanya sengketa terjadi pada saat rencana anggaran biaya yang terdapat di dalam perjanjian tidak sama dengan yang buat di lapangan. Biasanya orang sering mengatakan bahwa penerapan pekerjaan

\footnotetext{
${ }^{17}$ Seng Hansen. (2018). Manajemen Kontrak Konstruksi, Jakarta : PT.Gramedia Pustaka Utama.hlm.42

18 Bambang Poerdyatmono, “Alternatif Penyelesaian Sengketa Jasa Konstruksi”. Jurnal TeknikSipil, Vol. 8, No. 1, 2007, hlm. 78 - 90.
} 
lapangan tidak sama dengan "bestek", yaitu seperti gambar, dan spesifikasi teknis, dan instruksi owner dan pengawas pekerjaan.

Sengketa konstruksi adalah sengketa yang terjadi sehubungan dengan pelaksanaan suatu usaha jasa konstruksi antara para pihak yang tersebut dalam suatu kontrak konstruksi. Sengketa konstruksi terjadi akibat tuntutan atau klaim konstruksi tidak dipenuhi atau dilayani yang harus diselesaikan sesuai pilihan/kesepakatan para pihak sebagaimana tercantum dalam kontrak konstruksi.

Pilihan penyelesaian sengketa konstruksi, secara tegas biasanya dicantumkan dalam kontrak konstruksi. Dalam kontrak konstruksi terdapat pilihan forum dalam penyelesaian sengketa konstruksi. Sengketa kontrak konstruksi merupakan sengketa perdata, karena berkaitan dengan kontrak.

Karakteristik penyelesaian perkara atau sengketa jasa konstruksi dapat diselesaikan melalui pengadilan dan di luar pengadilan. Upaya penyelesaian sengketa jasa konstruksi di luar pengadilan dinyatakan dalam Pasal 58 Undang- Undang Nomor 48 Tahun 2009 tentang Kekuasaan Kehakiman bahwa "upaya penyelesaian sengketa perdata dapat dilakukan di luar pengadilan negara melalui arbitrase, atau alternatif penyelesaian sengketa".

Dalam Pasal 59 Undang-Undang Nomor 48 Tahun 2009 dikatakan bahwa "arbitrase merupakan cara penyelesaian suatu sengketa perdata di luar pengadilan yang didasarkan pada perjanjian arbitrase yang dibuat secara tertulis oleh para pihak yang bersengketa". Definsi ini hampir sama dengan definsi yang terdapat dalam Pasal 1 angka 1 Undang-Undang Nomor 30 Tahun 1999 tentang Arbitrase dan Alternatif Penyelesaian Sengketa dikatakan bahwa "Arbitrase adalah cara penyelesaian suatu sengketa perdata di luar peradilan umum yang didasarkan padaperjanjian arbitrase yang dibuat secara tertulis oleh para pihak yang bersengketa." Berdasarkan rumusan pasal 1 angka 1 di atas, ada tiga hal yang dapat dikemukakan UU No. 30 Tahun 1999 tersebut, yakni:

a. Arbitrase merupakan salah satu bentuk perjanjian

b. Perjanjian arbitrase harus dibuat dalam bentuk tertulis

c. Perjanjian arbitrase tersebut merupakan perjanjian untuk menyelesaikan sengketa yang dapat dilaksanakan di luar peradilan umum.

Subekti menyatakan bahwa arbitrase adalah penyelesaian atau pemutusansengketa oleh seorang hakim atau para hakim berdasarkan persetujuan bahwa para pihak akan tunduk pada atau menaati keputusan yang diberikan oleh hakim yang mereka pilih. ${ }^{19}$ Adapun menurut H. Priyatna Abdurrasyid menyatakan bahwa arbitrase adalah suatu proses pemeriksaan suatu sengketa yang dilakukan yudisial seperti oleh para pihak yang bersengketa, dan pemecahannya akan didasarkan kepada bukti-bukti yang diajukan oleh para pihak. $^{20}$

\footnotetext{
${ }^{19}$ Subekti, Arbitrase Perdagangan (Bandung: Bina Cipta, 1992), hal.1.
} 
Arbitrase sebagaimana dimaksud dalam UU No. 30 Tahun 1999 adalah cara penyelesaian suatu sengketa perdata di luar peradilan umum yang di dasarkanpada perjanjian arbitrase yang dibuat secara tertulis oleh para pihak yang bersengketa. Apabila para pihak telah terikat dalam perjanjian arbitrase maka pengadilan negeri tidak berwenang untuk mengadidli sengketa para pihak tersebut. ${ }^{21}$

Alternatif penyelesaian sengketa menurut Pasal 1 angka 10 Undang-Undang Nomor 30 Tahun 1999 adalah "lembaga penyelesaian sengketa atau beda pendapat melalui prosedur yang disepakati para pihak yakni penyelesaian di luar. pengadilan dengan cara konsultasi, negosiasi, mediasi, konsiliasi, atau penilaian ahli.

Pengertian alternatif penyelesaian sengketa yang terdapat dalam pasal tersebut hampir sama dengan pengertian alternatif penyelesaian sengketa yang terdapat dalam Pasal 60 Undang-Undang Nomor 30 Tahun 1999. Dalam Pasal 88 Undang-Undang Nomor 2 tahun 2017 tentang Jasa Konstruksi diatur tentang penyelesaian sengketa kontrak kerja konstruksi. Sengketa yang terjadi dalam kontrak kerja konstruksi diselesaikan dengan prinsip dasar musyawarah untuk mencapai kemufakatan. Dalam hal musyawarah para pihak tidak dapat mencapai suatu kemufakatan, para pihak menempuh tahapan upaya penyelesaian sengketa yang tercantum dalam kontrak kerja konstruksi.

Dalam hal upaya penyelesaian sengketa tidak tercantum dalam kontrak kerja konstruksi para pihak yang bersengketa membuat suatu persetujuan tertulis mengenai tata cara penyelesaian sengketa yang akan dipilih. Tahapan upaya penyelesaian sengketa meliputi:
a. mediasi;
b. konsiliasi; dan
c. arbitrase.

Selain upaya penyelesaian sengketa para pihak dapat membentuk dewan sengketa. Dalam hal upaya penyelesaian sengketa dilakukan dengan membentuk dewan sengketa, pemilihan keanggotaan dewan sengketa dilaksanakan berdasarkan prinsip profesionalitas dan tidak menjadi bagian dari salah satu pihak. Ketentuan lebih lanjut mengenai penyelesaian sengketa diatur dalam peraturan pemerintah, yaitu, Peraturan Pemerintah Nomor 14 Tahun 2021 Tentang Perubahan Atas Peraturan Pemerintah Nomor 22 tahun 2020 Tentang Peraturan Pelaksanaan Undang-undang Nomor 2 tahun 2017 tentang Jasa Konstruksi.

\footnotetext{
${ }^{20}$ H. Priyatna Abdurrasyid, Penyelesaian Sengketa Komersial Nasional dan Internasional diluar Pengadilan, Makalah, September 1996, hal. 1.

${ }^{21}$ Pasal 3 UU No. 30 Tahun 1999
} 
1. Penyelesaian sengketa Contractual, dapat melalui jalur-jalur sebagai berikut : Jalur Konsultasi Konsultasi merupakan suatu tindakan yang bersifat "personal" antara satu pihak tertentu, yang disebut dengan "klien" dengan pihak lain yaitu konsultan. Pihak konsultan ini memberikan pendapat kepada klien untuk memenuhi kebutuhan klien tersebut. Dalam jasa konstruksi, konsultan berperan penting dalam penyelesaian masalah- masalah teknis lapangan, apalagi apabila konsultan tersebut merupakan konsultan perencana dan atau konsultan pengawas proyek. Pendapat mereka sangat dominan untuk menentukan kelancaran proyek 2). Jalur Negosiasi Negosisi merupakan salah satu lembaga alternatif penyelesaian sengketa yang dilaksanakan di luar pengadilan, sedangkan perdamaian dapat dilakukan sebelum proses sidang pengadilan atau sesudah proses sidang berlangsung, baik di luar maupun di dalam sidang pengadilan. Dari literatur hukum dapat diketahui, selain sebagai lembaga penyelesaian sengketa, juga bersifat informal meskipun adakalanya juga bersifat formal.

2. Jalur Mediasi Dari beberapa pengertian yang ada, maka pengertian mediasi adalah pihak ketiga (baik perorangan atau lembaga independen), tidak memihak dan bersifat netral, yang bertugas memediasi kepentingan dan diangkat serta disetujui para pihak yang bersengketa. Sebagai pihak luar, mediator tidak memiliki kewenangan memaksa, tetapi bertemu dan mempertemukan para pihak yang bersengketa guna mencari masukan pokok perkara. Berdasarkan masukan tersebut, mediator dapat menentukan kekurangan atau kelebihan suatu perkara, kemudian disusun dalam proposal yang kemudian dibicarakan kepada para pihak secara langsung. Peran mediasi ini cukup penting karena harus dapat menciptakan situasi dan kondisi yang kondusif sehingga para pihak yang besengketa dapat berkompromi dan menghasilkan penyelesaian yang saling menguntungkan di antara para pihak yang bersengketa. Mediasi juga merupakan salah satu alternatif penyelesaian sengketa. 4). Jalur Perdamaian Jalur perdamaian merupakan atau langkah awal sebelum sidang pengadilan dilaksanakan, dan ketentuan perdamaian yang diatur dalam Kitab Undang-undang Hukum Perdata, juga merupakan bentuk alternatif penyelesaian sengketa di luar pengadilan, dengan mengecualikan untuk hal-hal atau sengketa yang telah memperoleh suatu putusan hakim yang telah mempunyai kekuatan hukum tetap. 4). Jalur Pendapat Hukum oleh Lembaga Arbitrase Arbitrase adalah bentuk kelembagaan, tidak hanya bertugas untuk menyelesaikan perbedaan atau perselisihan atau sengketa yang terjadi antara para pihak dalam perjanjian pokok, akan tetapi juga dapat memberikan konsultasi dalam bentuk opini atau pendapat hukum atas permintaan para pihak dalam perjanjian. Pendapat hukum lembaga 
arbitrase bersifat mengikat, dan setiap pelanggaran terhadap pendapat hukum yang diberikan tersebut berarti pelanggaran terhadap perjanjian

\section{Penutup}

Setelah terbitnya UU No. 2/2017 tentang Jasa Konstruksi, sengketa konstruksi terlebih dahulu diselesaikan melalui musyawarah untuk mufakat. Apabila para pihak yang bersengketa tidak menemukan kesepakatan, maka penyelesaian ditempuh melalui tahapan penyelesaian sengketa yang diatur dalam kontrak kerja konstruksi. Kemudian apabila penyelesaian sengketa tidak tercantum dalam kontrak kerja konstruksi, maka para pihak dengan persetujuan tertulis mengatur mengenai tata cara penyelesaian sengketa yang dipilih.

Untuk tahapan-tahapan penyelesaian sengketa sesuai UU No. 2/2017 adalah:

1. Para pihak yang bersengketa terlebih dahulu melakukan musyawarah untuk mufakat;

2. Apabila musyawarah tersebut tidak tercapai, maka penyelesaian sengketa disesuaikan berdasarkan kontrak kerja konstruksi;

3. Apabila penyelesaian sengketa tercantum dalam kontrak, makapenyelesaian sengketa ditempuh melalui tahapan sebagai berikut:

4. Mediasi;

5. Konsiliasi, dan;

6. Arbitrase

7. Jika penyelesain sengketa tidak tercantum dalam kontrak kerja konstruksi, maka para pihak yang bersengketa membuat tata cara penyelesaian yang dipilih

\section{Daftar Pustaka}

Bambang Poerdyatmono, “Alternatif Penyelesaian Sengketa Jasa Konstruksi”. Jurnal Teknik Sipil, Vol. 8, No. 1, 2007

F.X. Djumialdji (1), Hukum Bangunan, Dasar-Dasar Hukum dalam Proyek danSumber Daya Manusia, (Jakarta : PT. Rineka Cipta, 1996)

F.X. Djumialdji (2), Perjanjian Pemborongan, (Jakarta : PT. Rineka Cipta, 1991) Frans Hendra Winata, Hukum Penyelesaian Sengketa, Sinar Grafika, Jakarta, 2012

Gatot Soemartono, arbitrase dan mediasi di Indonesia, PT Gramedia Pustaka Utama, Jakarta 2006

H. Priyatna Abdurrasyid, Penyelesaian Sengketa Komersial Nasional dan Internasional diluar Pengadilan, Makalah, September 1996

I Wayan Wiryawan \& I Ketut Artadi, Penyelesaian Sengketa Di Luar Pengadilan. Denpasar -Bali : Udayana University Press, 2010

Mestika Zed, Metodologi Kepustakaan. (Jakarta: Yayasan Obor Indonesia, 2008)

Nazharkhan Yasin, Mengenal Klaim Konstruksi dan penyelesaian sengketakonstruksi, PT Gramedia Pustaka Utama, Jakarta 2008

Nurnaningsih Amriani, Mediasi Alternatif Penyelesaian Sengketa di Pengadilan, Grafindo Persada, Jakarta, 2012,

Peter Mahmud Marzuki, 2011, Penelitian Hukum, Jakarta: Kencana PrenadaMedia Grup Sarwono,2012, HUKUM ACARA PERDATA Teori dan Praktik, Jakarta: SinarGrafika Seng Hansen. (2018). Manajemen Kontrak Konstruksi, Jakarta : PT.Gramedia Pustaka Utama

Soerjono Soekanto, 1986, Pengantar Penelitian Hukum, Jakarta: UI Pres

Soerjono Soekanto, Pengantar Penelitian Hukum, Jakarta: Universitas Indonesia press, 1986

Subekti, Arbitrase Perdagangan (Bandung: Bina Cipta, 1992) 
Sugianto Darmadi, 1988, Kedudukan ilmu Hukum dalam Ilmu dan Filsafat, Bandung: Bandar Maju

Suyud Margono, ADR dan Arbitrase: Proses Pelembagaan dan Aspek Hukum, Ghalia Indonesia, Bogor, 2004,

Takdir Rahmadi, Mediasi Penyelesaian Sengketa Melalui Pendekatan Mufakat, Rajawali Pers, Jakarta, 2011

Winardi, Managemen Konflik (Konflik Perubahan dan Pengembangan), Mandar Maju, Bandung, 2007

Yahya Harahap, Beberapa Tinjauan Mengenai Sistem Peradilan dan Penyelesaian Sengketa, Citra Aditya Bakti, Bandung, 1997

Yahya Harahap, Hukum Acara Perdata Tentang Gugatan, Persidangan, Penyitaan, Pembuktian, dan Putusan Pengadilan, Sinar Grafika, Jakarta, 2009 